\title{
Esterification of peat by mechanochemical method
}

Efanov M.V. ${ }^{1}$, Konshin V.V. ${ }^{2}$, Sartakov M.P. ${ }^{3}$

${ }^{1}$ LLC "MIP "Yugra - Biotechnology", Khanty-Mansiysk, Russia, efanov_1973@mail.ru

${ }^{2}$ Altay state technical university, Barnaul, Russia

${ }^{3}$ Yugra state university, Khanty-Mansiysk, Russia

doi: 10.36291/HIT.2019.efanov.112

Peat is a unique natural composite, a source of humic substances and raw materials for industry and agriculture. The aim of this work is to develop a new acylated thermoplastic binder from peat to study the possibility of its application in the industry of plate materials [1]. The esterification of peat was carried out in the processing of lowland peat acetic anhydride by mechanochemical method with different molar ratio of reagents from 1:1:0.5 to $1: 1: 2.5$ for $30 \mathrm{~min}$ at $25{ }^{\circ} \mathrm{C}$. The chemical composition of products of esterification of peat given in the table 1.

Table 1. The influence of the molar ratio of $\mathrm{OH}: \mathrm{Ac}_{2} \mathrm{O}$ in the acetylation of peat in conditions of intensive mechanical grinding on the properties of the obtained products*

\begin{tabular}{ccccc}
\hline Sample & $\begin{array}{c}\text { Mole ratio } \\
\mathrm{OH}: \mathrm{Ac}_{2} \mathrm{O}\end{array}$ & $\begin{array}{c}\text { Content of acetyl } \\
\text { groups, } \%\end{array}$ & $\begin{array}{c}\text { Solubility in } \\
\text { acetone, } \%\end{array}$ & $\begin{array}{c}\text { Conversion OH- } \\
\text { groups, \% }\end{array}$ \\
\hline Peat & - & - & 5 & - \\
\hline 1 & $1: 0,5$ & 10.5 & 20 & 42 \\
\hline 2 & $1: 1$ & 11.7 & 30 & 47 \\
\hline 3 & $1: 2$ & 15.2 & 47 & 61 \\
\hline 4 & $1: 3$ & 17.8 & 60 & 71 \\
\hline
\end{tabular}

*the mass of peat is $10.0 \mathrm{~g}$, the temperature of the acetylation $-50{ }^{\circ} \mathrm{C}$, the duration of the acetylation -60 $\min$.

It was found that with an increase in the molar ratio there is an increase in the content of bound acetyl groups in products and their solubility in acetone (table 1).

The influence of duration mechanochemical treatment of peat on the process of xanthogenation under the action of carbon disulphide in the presence of $\mathrm{NaOH}$ (table 2) [2].

Table 2. Xanthogenation of peat

\begin{tabular}{ccc}
\hline $\begin{array}{c}\text { Duration xanthogenation of } \\
\text { peat, min }\end{array}$ & Content $\mathrm{CS}_{2}, \%$ & Solubility in water, \% \\
\hline 10 & 3.6 & 25 \\
\hline 20 & 5.0 & 37 \\
\hline 30 & 6.9 & 69 \\
\hline 40 & 9.0 & 72 \\
\hline 50 & 11.2 & 89 \\
\hline 60 & 15.4 & \\
\hline
\end{tabular}

It is shown that the increase in the duration xanthogenation of peat is the increase in the content and solubility products in water (table 2).

Acknowledgements. Thank you for submission of your abstract RFBR (project № 1843-860001_p_a).

References

1. Efanov M.V. Method of producing the binder from peat. // Patent of Russian Federation № 2614671. Published 28.03.2017. Bulletin № 10.

2. Efanov M.V., Filina E.S. // Chemistry of natural compounds. 2004. 2:151-153. 